\title{
First, do no harm
}

\section{William P. Butz*}

At a conference on the theme "Can policies enhance fertility in Europe?", presentations and discussion would naturally assume that very low fertility rates will not increase on their own accord, but will instead require the nudge or bludgeon of policy. Indeed, by my reckoning, some four-fifths of conference discussion was explicitly or implicitly based on this assumption. Outside these halls, it is the same. One sees little optimism in the academic or popular press that fertility rates might spontaneously rebound. Instead, there as here, the discussion turns now to policies that might induce couples to bear and raise more children or, failing that, policies that might mitigate the undesirable effects of fertility rates persisting well below the replacement level for a long time.

I argue here a contrary view: Fertility in Europe is as likely to rise over the next ten years as it is to stay low or fall further. ${ }^{1}$ I argue that we do not know what will happen, that we do not know enough, in fact, to project one future over another.

This agnostic forecast implies no corollary that governments leave fertility rates alone or that researchers turn their attention elsewhere. To the contrary, the likely consequences of continuing very low fertility are serious enough that the phenomenon deserves much more research and policy attention than at present, this even if, as I argue, the prospect of continuing low fertility is no higher than the prospect of fertility increases.

What my forecast does imply, however, is that among the possibly pronatalist policies available, governments should consider only those that do no harm to couples or society. Such policies would be deemed desirable, even if it turns out that they are unnecessary or ineffective in raising fertility. Fortunately, some policies under researchers' and policymakers' microscopes meet this criterion, for example, policies that provide child day care or otherwise reduce the conflicts between parent's employment and child care. By common reckoning, such policies would be desirable on grounds other than fertility enhancement. To the contrary, some other policies may impose costs to couples or society that would be unacceptable if the additional fertility they induce turns out not to be needed,

* William P. Butz, Population Reference Bureau, 1875 Connecticut Ave., NW Suite 520, Washington, D.C. 20009-5728, USA. Opinions expressed are those of the author and not necessarily those of the Population Reference Bureau. Email: butz@prb.org

1 This scenario of rising fertility could be consistently measured in number of births, total fertility rate, or tempo-adjusted total fertility rate, all increasing. 
for example, appeals to national interest that persuade some couples to have more children than they want or can afford.

My agnostic fertility forecast rests on three legs-recent European fertility trends; a historical parallel; and the state of population science.

\section{Recent European fertility trends}

Of the 39 European countries that have published total fertility rates (TFR) for 2007, 17 record higher TFRs in 2007 than in 2000 (Population Reference Bureau 2007). In northern Europe it is 8 out of 10, in western Europe 1 out of 8, in eastern Europe 4 out of 10 and in southern Europe it is 4 out of 11. In some of the countries, the increase is slight, not enough that we would pay attention if trends had not been in the opposite direction. And in several, much of the increase is due to the higher fertility of immigrants.

There is argument and evidence that these levellings and increases are tempo effects - attributable to couples making up for earlier delayed fertility- that will leave completed fertility unchanged (Bongaarts 2008). Although it may turn out so, no scholar to my knowledge projected the European fertility experience of recent years from the vantage point of 2000, based on a tempo model or any other (Lutz et al. 2006). Following two or three decades of declining fertility to historic lows, these recent levellings and increases would seem worthy of serious notice.

\section{A historical parallel}

By the late 1930s, some prominent population researchers in Europe and the United States were projecting a future of secularly declining population growth followed by declining absolute numbers. And why not? After more than a century of decreasing fertility rates in most industrialised countries, there was no reason to expect a sea change. Most prominent in the US was Joseph Spengler, presidentto-be of the Population Association of America, writing in 1938:

"Within the next quarter century true depopulation-a persistent long-run excess of deaths over births - will manifest itself in nearly all the countries of Europe and in those non-European countries to which Western civilisation has spread. The present stream of concern over eventual depopulation-concern evident in the many European works dealing with depopulation, in the depopulationist inquiries being made in countries such as England and Sweden, and in the anti-depopulation measures already put into effect in certain countries-will assume the proportions of a deluge. The growth of alarm at depopulation in various countries will proceed along the lines of a rather definite and somewhat 'naturally evolving' pattern and will be accompanied by the enactment of a sequence of ineffectual measures designed to stem the decline in fertility." (Spengler 1938).

Meanwhile, the economist Alvin Hansen argued in his 1939 presidential address to the American Economic Association that the growth ingredients in the American economy, mainly population growth and technological innovation, had 
played out (Hansen 1939). The economy could not ever again grow rapidly. Hansen's "secular stagnation" hypothesis fit well with John Maynard Keynes' model of modern capitalist economies, published several years earlier, in which population growth was one factor fuelling the aggregate demand for goods and services (Keynes 1936). Hansen concluded that only continued and increasing deficit spending on the part of governments could save modern capitalist economies from ruinous stagnation.

Not a decade after Spengler, Hansen and others were raising this alarm came the "baby boom" in these same countries. Secular stagnation and the broader worries about population declines disappeared.

\section{The state of population science}

One objective of population science is to provide useful theories, that is, conceptual constructs yielding predictions that are refutable by evidence. Most of the theories that have yielded such predictions, in the case of fertility in developed countries, are the work of economists (see, for example, these foundational studies: Leibenstein 1954, Becker 1960, Freedman 1963, Easterlin 1968, Willis 1973, Butz and Ward 1979, van de Kaa 1987.) In the domain of time series fertility, their predictions have not fared well. Subsequent revisions to fit emerging data have generally weakened confidence in the theories' predictions more than they have strengthened the predictions' accuracy. Rarely, to my knowledge, has a population researcher produced a theory-based prediction of secularly increasing European fertility rates in the 21st century (but see James Feyrer et al. 2008). If the current boomlet outlasts the possibility of a tempo correction, then the poverty of our theorising will be evident. If, on the other hand, the boomlet peters out, then attention must be paid to the low fertility trap model of Lutz and colleagues (Lutz et al. 2006).

European countries have over the last quarter century displayed a rich variety of fertility-related behaviour as well as policies hypothesised to influence it. Such a laboratory for the social sciences is rare. From it, population scientists have so far gleaned little in the way of regularities. Nearly every hypothesis relating policy to fertility outcomes quickly finds a clear exception, sometimes in analyses of family level data but usually in the glare of a country-level comparison.

\section{Do no harm}

In the face of some kind of fertility levelling or increase across Europe, with history's cautionary example, and without well-tested theory to guide our expectations, I believe population researchers cannot know with any confidence at all the near-term course of European fertility. Teitelbaum and Winter (1985), writing half a century after the unrealised secular stagnation predictions of the 1930s, chronicled the history of concerns about population declines and the fertility upturns that almost invariably put an end to these concerns. They suggested implicitly that countries thinking that they face population decline 
today-Europe in particular—not adopt policies that their descendents might regret. Good advice.

\section{References}

Becker, G. S. 1960. “An economic analysis of fertility.” In: Demographic and Economic Change in Developed Countries. NBER Conference Series, Vol. 11, Princeton, NJ: National Bureau of Economic Research, pp. 209-240. Available at: «http://www.nber.org/chapters/c2387.pdf».

Bongaarts, J. 2008. "What can fertility indicators tell us about pronatalist policy options?" Vienna Yearbook of Population Research 2008: 38-55.

Butz, W. P. and M. P. Ward. 1979. "The emergence of countercyclical U.S. fertility." American Economic Review 69(3): 318-328.

Easterlin, R. 1968. Population, Labor Force, and Long Swings in Economic Growth: the American Experience. New York, Columbia University Press

Feyrer, J., B. Sacerdote, and A. D. Stern. 2008. "Will the stork return to Europe and Japan? Understanding fertility within developed nations." Journal of Economic Perspectives 22(3): 3-22.

Hansen, A. 1939. "Economic progress and declining population growth." American Economic Review 29 (March):1-15..

Keynes, J. M. 1936. The Theory of Employment Interest and Money. New York, Harcourt, Brace and World, Inc.

Freedman, D. S. 1963. "The relation of economic status and fertility." American Economic Review 53(3): 412-426.

Leibenstein, H. 1954. A Theory of Economic-Demographic Development. Princeton, NJ, Princeton University Press.

Lutz, W., B. O'Neill, and S. Scherbov. 2003. "Europe's population at a turning point." Science 299: 1991-1992.

Lutz, W., V. Skirbekk, and M. R. Testa. 2006. "The low fertility trap hypothesis: Forces that may lead to further postponement and fewer births in Europe." Vienna Yearbook of Population Research 2006: 167-192.

Population Reference Bureau. 2007. Fertility Rates for Low Birth-Rate Countries, 1995 to Most Recent Year. Accessed at «http://www.prb.org/pdf07/TFRTable.pdf».

Spengler, J. J. 1938. France Faces Depopulation. Durham, Duke University Press.

Teitelbaum, M. S. and J. M. Winter. 1985. The Fear of Population Decline. San Diego, Academic Press, Harcourt Brace Jovanovich.

van de Kaa, D. J. 1987. “Europe’s Second Demographic Transition.” Population Bulletin 42(1), Population Reference Bureau.

Willis, R. 1973. "A new approach to the economic theory of fertility behavior." Journal of Political Economy, 81(part 2, March-April): S14-S64. 